\title{
Trichosporon isolation from human ungueal infections: is there a pathogenic role?
}

\author{
Alba Regina de Magalhães ${ }^{1}$ \\ Silvia Suzana Bona de Mondino ${ }^{1}$ \\ Elisabeth Martins da Silva da Rocha ${ }^{1}$
}

\author{
Marília Martins Nishikawa \\ Heloisa Werneck de Macedo ${ }^{1}$ \\ Andrea Regina de Souza Baptista ${ }^{1}$
}

DOI: http:/ / dx.doi.org/10.1590/abd1806-4841.20164632

\begin{abstract}
BACKGROUND: Although dermatophytes are considered the major cause of onychomycosis, many reports have incriminated non-dermatophyte moulds and yeasts in the disease's etiology. Successive Trichosporon isolation from onychomycosis has led to the genus being suspected as a nail primary pathogen.

OвJестіVE: To determine the prevalence of Trichosporon isolation in onychomycosis patients who attended a mycology diagnostic service in Rio de Janeiro, Brazil, between January 2003 and December 2006. The study also includes a worldwide review on Trichosporon isolation prevalence in ungueal disease, emphasizing T. ovoides. MetHods: This retrospective study was conducted with the support of staff from the Mycology Laboratory at the Dermatological Service of Rio de Janeiro's Santa Casa da Misericórdia (MLDS).

REsults: Mycological analysis provided positive results equaling 47/5036 (0.93\%) for Trichosporon spp.; obtained mainly as a single agent $(72.35 \%)$, and from mixed cultures $(27.65 \% ; \mathrm{X} 2=6.397 ; \mathrm{p}=0.018)$. The great majority belongs to the T. ovoides species $(91.5 \% ; n=43)$, obtained as a single isolate $(74.41 \% ; n=32 / 43 ; \mathrm{X} 2=7.023 ; \mathrm{p}=0.014)$. ConClusions: Although T. ovoides is classically associated as an etiologic agent of white piedra, this study highlights its potential as a human nail disease pathogen. Our study opens doors for future epidemiologic and virulence factors aimed at determining whether T. ovoides is an important causative agent of onychomycosis in Brazil. Keywords: Diagnosis; Nail diseases; Trichosporon; Trichosporonosis.
\end{abstract}

\section{INTRODUCTION}

Onychomycosis is characterized by nail thickening and distrophy, and may also affect the surrounding skin. Due to its prevalence, it represents a public health problem which affects mainly the elderly and, especially, diabetic subjects. In addition to esthetic and emotional harm, it can be painful and prevent daily activities and/or aggravate pre-existing conditions. ${ }^{1,2}$ The frequency of yeast isolation from onychomycosis has increased over the last years, which has been attributed to both local and systemic factors including continuous finger exposure to humidity, antibacterial drug prophylaxis and treatment with immunosuppressive drugs. ${ }^{3}$
Although dermatophytes are considered the major cause of onychomycosis, many reports have incriminated non-dermatophyte moulds and yeasts in the etiology of ungueal disease. ${ }^{4,5,6}$ Among yeasts, the Candida genus is frequently isolated from such lesions whereas moulds are represented by Fusarium, Aspergillus, Alternaria, Curvularia species and Scytalidium dimidiatum. ${ }^{2,6}$

The Trichosporon Behrend genus has been continuously revised by biochemical and molecular tools, resulting in the establishment of the 6 major human pathogens: T. asahii, T. mucoides, T.ovoides, T. asteroides, T. cutaneum and T. inkin ${ }^{7,8,9,10}$, plus 15 other species of medical significance. ${ }^{11}$ These are causative agents

Received on 13.04 .2015

Approved by the Advisory Board and accepted for publication on 19.07.2015

Work performed at the Laboratório de Micologia Médica e Molecular - Departamento de Microbiologia e Parasitologia do Instituto Biomédico - Universidade Federal Fluminense (UFF) - Niterói (RJ), Brasil.

Financial Support: PROPPI/UFF.

Conflict of Interest: None.

Universidade Federal Fluminense (UFF) - Niterói (RJ), Brazil.

Fundação Oswaldo Cruz (FIOCRUZ) - Rio de Janeiro (RJ), Brazil.

(C)2016 by Anais Brasileiros de Dermatologia 
of benign superficial lesions, classically the white piedra, determined by the presence of head and pubic hair nodules due to T. ovoides and T. inkin, respectively. ${ }^{7,8}$ Furthermore, frequent reports of allergic pneumonia and invasive trichosporonosis have been published, as reviewed by Chagas-Neto et al. $^{5}$ and Colombo et al. ${ }^{11}$ The considerable frequency of Trichosporon spp. isolation from onychomycosis has led to the genus being suspected as a nail primary pathogen, other than a secondary colonizer following dermatophyte nail infection. 12,13

This study sought to determine Trichosporon isolation prevalence in onychomycosis patients who attended a mycology diagnostic service in Rio de Janeiro, Brazil. It also includes a worldwide review on Trichosporon spp. isolation prevalence in ungueal disease, focusing on its potential pathogenic role.

\section{MATERIALS AND METHODS}

This retrospective study was conducted by staff from the Mycology Laboratory at the Dermatological Service of Rio de Janeiro's Santa Casa da Misericórdia (MLDS) between January 2003 and December 2006. A total of 7,527 patients were advised to seek a mycology diagnostic service because they had hair, skin and/or ungueal lesions, suggesting superficial mycosis, as evaluated by physicians from Rio de Janeiro. They all underwent further analysis for fungal agents by the MLDS staff. The study included 47 patients, all of whose mycological exams returned positive results for Trichosporon.

\section{Mycological Analysis}

To obtain the specimens used in this study, MLDS biologists scraped fingernail and/or toenail lesions with a surgical blade, as classically described in dermatology guidelines. The material was immediately sent for examination by direct $\mathrm{KOH}$ treatment and inoculation in Sabouraud glucose agar, with and without chloramphenicol and cycloheximide (BD, New Jersey, US). All tubes were cultivated at $25^{\circ} \mathrm{C}$ for up to 30 days. Direct examination was considered positive for fungus whenever yeast-like and/or hyphae were seen under light microscopy. Yeasts suggestive of the Thichosporon genus were purified and preserved in Skim Milk (DIFCO, USA) solution at $20 \%(\mathrm{w} / \mathrm{v})$ for further identification, based on their morphological and biochemical characteristics. To identify species, growth at $37^{\circ} \mathrm{C}$, assimilation tests and cycloheximide tolerance tests were performed. ${ }^{14}$ Identification was carried out via culture, first by screening colonial and microscopic morphology, then by analyzing the species': physiological growth characteristics on carbon and nitrogen sources (assimilation patterns), ability to hydrolyze urea, growth in $0.1 \%$ and $0.01 \%$ cyclo- heximide, and the presence of appressorial cells, as previously detailed. ${ }^{15}$ Reference microorganisms $T$. ovoides INCQS 40270 (ATCC 90040) and T. inkin INCQS 40266 (ATCC 18020), acquired from the American Type Culture Collection and maintained in the Culture Collection of Instituto Nacional de Controle de Qualidade (INCQS), were used as control to identify the species in this investigation's various tests.

\section{Ethical aspects}

The research protocol was submitted to the Research Ethics Committee at the Santa Casa de Misericórdia of Rio de Janeiro and approved on June $16^{\text {th }}, 2007$ (protocol number 016/07).

\section{Statistical analysis}

Statistical analysis was performed using the Epi-Info statistics program (version 6.0). The chisquare 2 test was applied to obtain independence between proportions. Using the binomial test, the relationship between the participants' clinical characteristics and of Trichosporon spp. isolation was assessed. The level of significance adopted for statistical inference was $5 \%$.

\section{RESULTS}

Laboratory analysis revealed an onychomycosis prevalence of $66.9 \%$ (5036/7527), as determined after direct examination and positive culture. Forty-seven patients had positive results for Trichosporon spp., all from a single infection site (toenail or fingernail); the majority were women $(35 / 47 ; \mathrm{p}=0.001)$, aged 50-70 years, living in the metropolitan region of Rio de Janeiro. Likewise, isolating this genus among all patients diagnosed with onychomycosis presented a prevalence of $0.93 \%$ (47/5036). Trichosporon isolation varied according to patients' sex and anatomic site; women's fingernails were affected more frequently (24/47) than both, men (12/47) and women's toenails (11/47; binomial test $\mathrm{p}=0.008)$. T. ovoides isolation yielded a heterogeneous distribution which varied according to age groups $\left(X^{2}=31,396 ; p=0.0001\right)$, entailing a major concentration in individuals aged 61-70 years and a significant reduction among two groups: the $11-20$ and $81-90$ age groups $(p<0.05$; Table 1$)$.

Trichosporon was obtained mainly as a single agent $(34 / 47 ; 72.35 \%)$, but also from mixed cultures $(13 / 47 ; 27.65 \%$; Table 1$)$, with one additional yeast, mould or dermatophyte $\left(\mathrm{X}^{2}=6.397 ; \mathrm{p}=\right.$ $0.018)$. The vast majority of all Trichosporon recovered were T. ovoides $(91.5 \% ; \mathrm{n}=43)$ as a single isolate $(74.41 \%$; $\left.n=32 / 43 ; X^{2}=7.023 ; p=0.014\right)$, while the remaining could not be identified to the species level. T. ovoides was also detected in mixed cultures from ungueal scraping, along with dermatophytes (two Tricophyton 
TABLE 1: Trichosporon spp. according to onychomycosis site (fingernails or toenails), number of isolates and culture results of patients from Rio de Janeiro; obtained between January 2003 and December 2006

\begin{tabular}{llll}
\hline Onychomycosis site & Trichosporon ovoides & Trichosporon spp. & Number (\%) of Isolates \\
\hline Ungueal & 43 & 4 & 47 \\
$\quad$ Fingernails & $28(87,5 \%)$ & $4 \quad(12,5 \%)$ & $32(68.1)$ \\
$\quad$ Toenails & $15(100 \%)$ & - & $15(31.9)$ \\
Culture & & & \\
$\quad$ Mixed & 11 & $2^{*}$ & $13(\%)$ \\
Single & 32 & 2 & $34(\%)$ \\
TOTAL & 43 & 4 & $47(100)$ \\
\hline
\end{tabular}

*T. mentagrophytes and Candida spp.

rubrum and one Tricophyton mentagrophytes; 3/43), yeast (four Candida spp.; 4/43) and moulds (two Fusarium spp. and two Scytalidium dimidiatum; 4/43). All fungi recovered from toenails resulted in the identification of T. ovoides. The non-identified species from the genus $(n=4)$ were either isolated together with Candida spp. and T. mentagrophytes (one each), or as the only fungi recovered $(n=2)$.

\section{DISCUSSION}

In 1976, in Colombia, Restrepo and Uribe were the first to suspect Trichosporon was a human nail pathogen. Later, in 1984, Fusaro and Miller described the first case of onychomycosis by this genus in a normal, healthy man living in the US. ${ }^{16,17}$ Following these pioneering reports, other authors, studying different populations, uncovered data supporting the same hypothesis. ${ }^{12,13,18-25}$ In addition, the first report of T. montevideense involvement in a Japanese monkey (Macaca fuscata) with onychomycosis revealed that the genus was potentially a nail pathogen in vertebrates other than humans. ${ }^{26}$ However, establishing Trichosporon as a human nail pathogen is difficult because of its frequent isolation, either: as a member of the normal skin surface microbiota and appendages, or from mixed cultures along with classical nail pathogens such as Tricophyton rubrum. ${ }^{2,12,16}$ Although T. ovoides is classically recognized as one of white piedra's etiologic agents, this investigation highlights its isolation as well as other Trichosporon species from human nail disease worldwide, discussing its potential pathogenic role.

Onychomycosis is the most common human nail disease with an overall frequency ranging from $18 \%$ to $73 \%$, influenced by factors including geographical location, climate, cultural habits and genetic background. ${ }^{2,3}$ Our study has a high prevalence (66.9\%), probably due to Rio de Janeiro's hot and humid climate. While we detected a $0.93 \%$ frequency for Trichosporon isolation from onychomycosis, mainly T. ovoides single isolates (74.4\%), other authors have reported frequencies varying from $0.54 \%$ to $8 \%$ for the same genus, in different Brazilian populations (Graph 1 and Table 2). Interestingly, in Rio de Janeiro State, two reports revealed great variation: one found a similar frequency to ours $(0.87 \%)^{20}$, whereas the other study's was higher $(8 \%)^{2}$ - close to rates mentioned in reports on different populations, for instance in Turkey $(9.49 \%)^{23}$, Korea $(10.1 \%)^{12}$ and Nigeria $\left.(10.3 \%)\right)^{18}$ Apart from Brazil, in South America, only Colombians have been studied in two distinct decade reports, showing diverse frequencies of $5.53 \%$ and $1.08 \%{ }^{16,27}$ Intermediate numbers have been obtained in different countries and in other Brazilian states, as described in table 2.

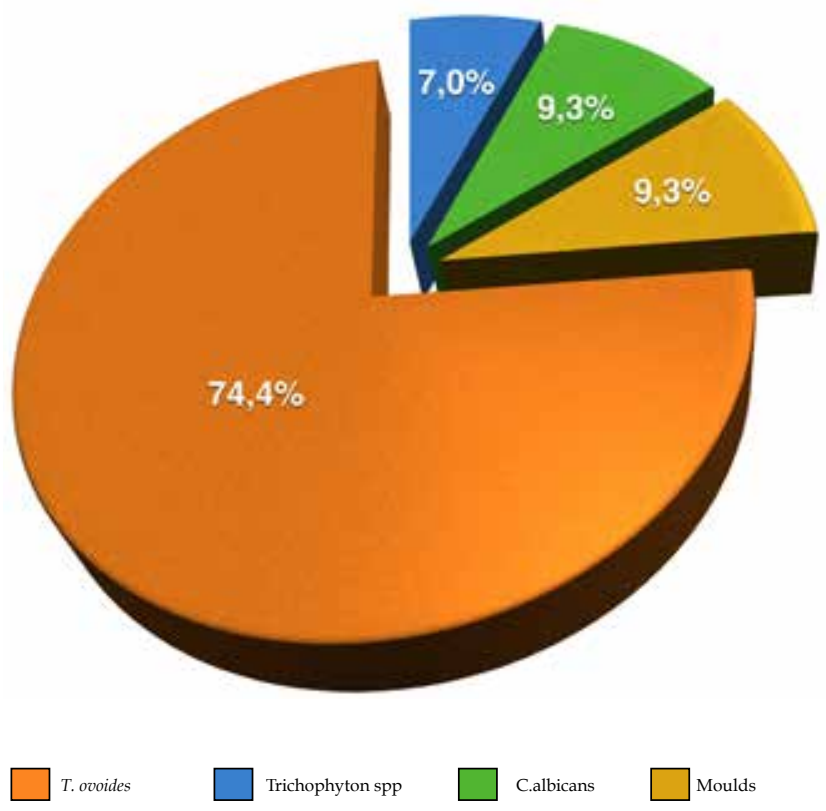

GraPH 1: Frequency of Trichosporon ovoides obtained from onychomycosis as a single isolated yeast $(74.4 \%)$ or along with other fungi (dermatophytes, Candida albicans or moulds) 


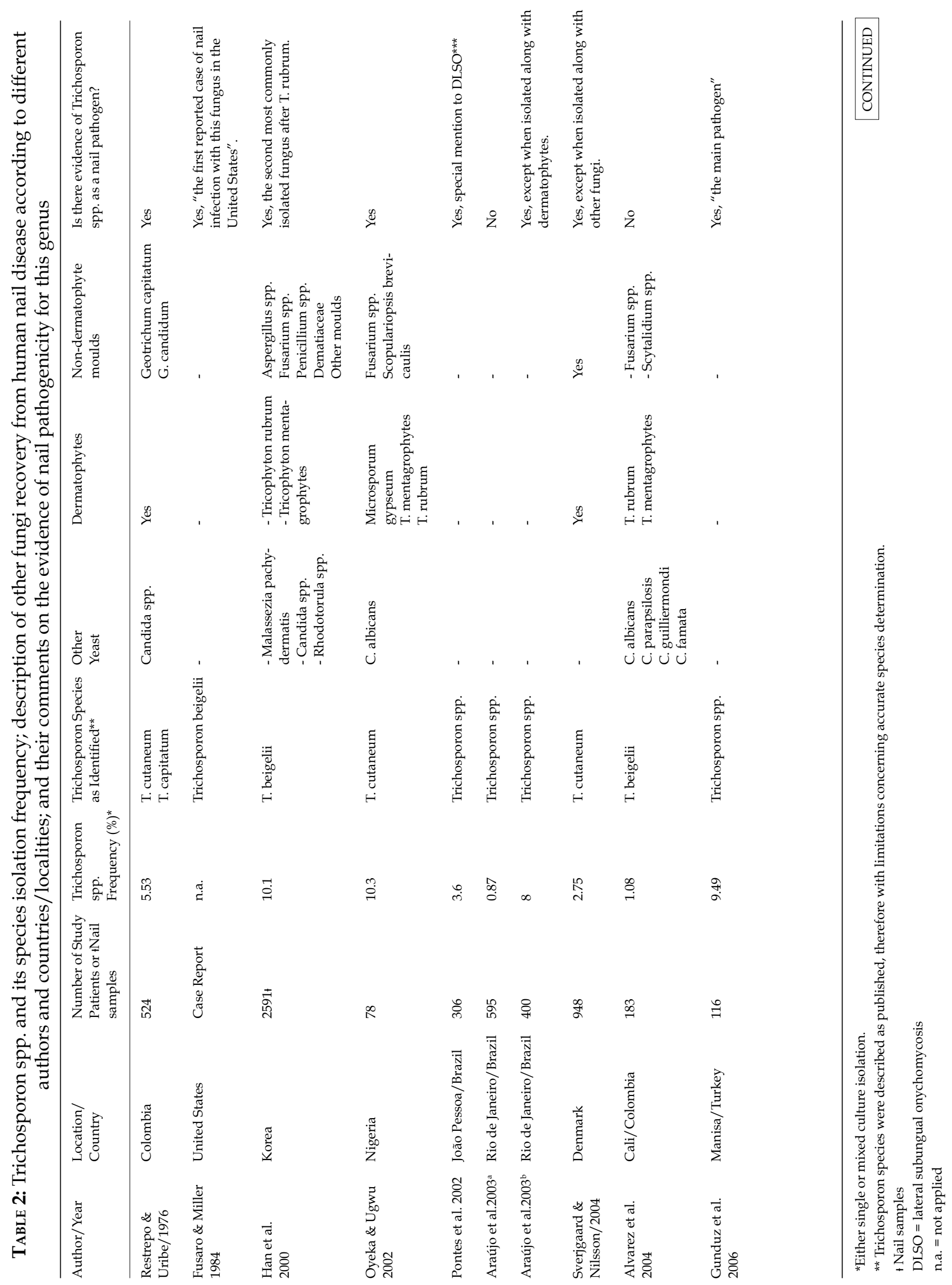



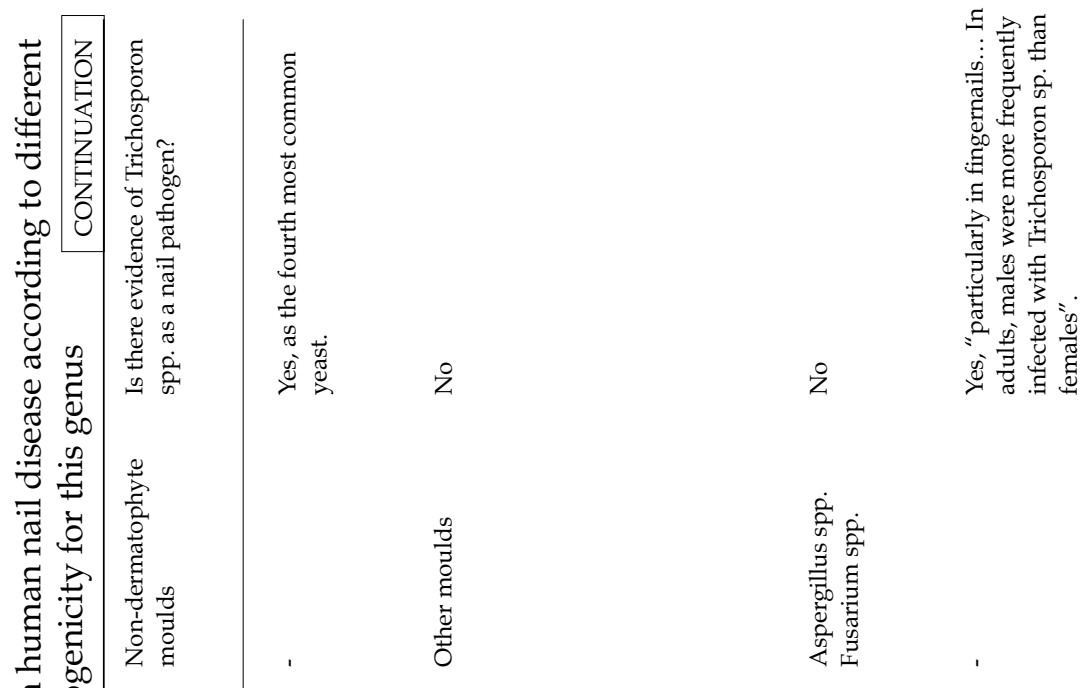

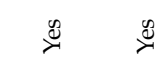
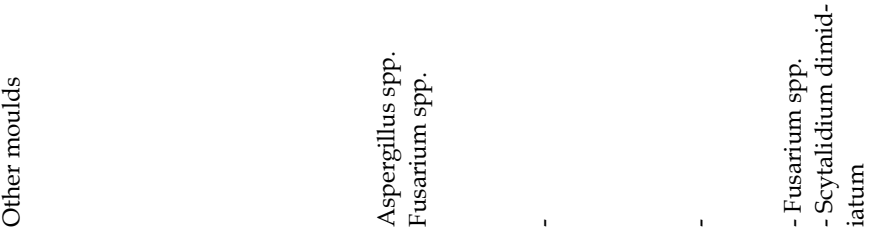

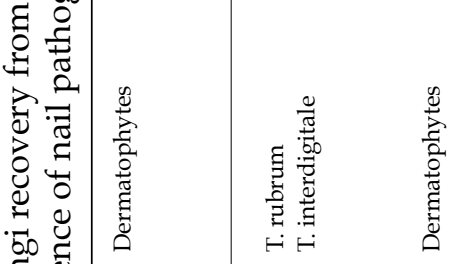

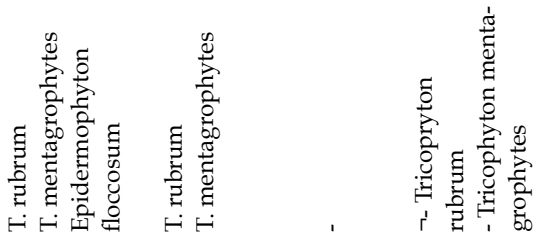

3.

害

(1)

ఫ车

प艹

.ี

密

恖

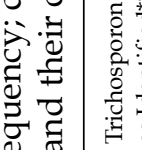

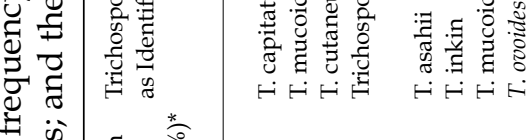

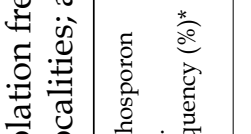

.

.

क

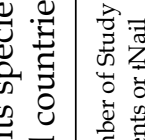

च छ

คे

का

की

离

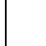

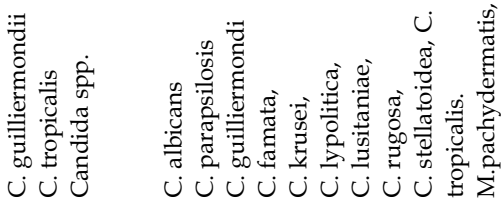

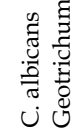

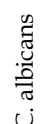

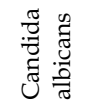

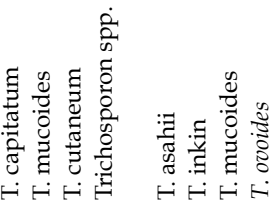

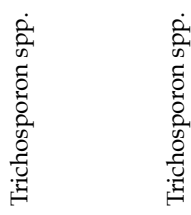

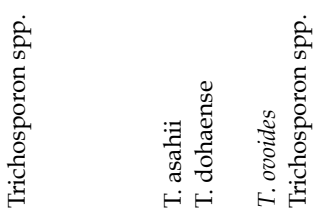

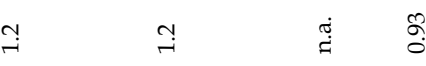

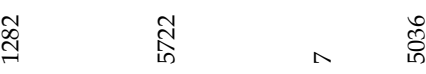

突 สำ

ส

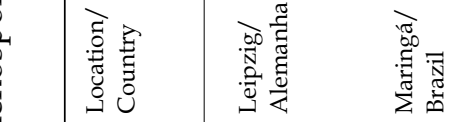

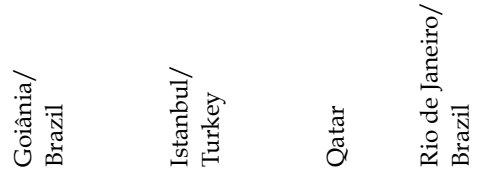

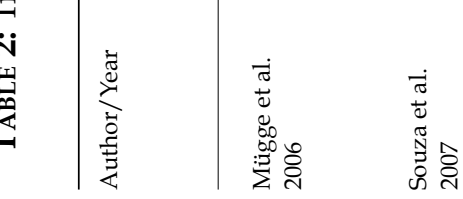

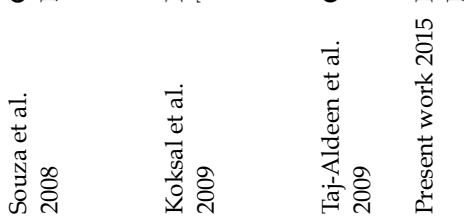

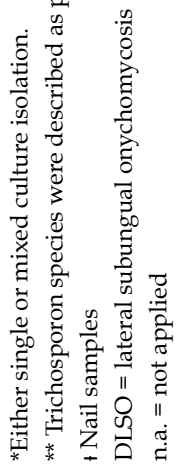


Although previous investigations have suggested Trichosporon is a nail pathogen - or even refer to it as such - most do not identify this genus to the species level or only describe $T$. beigelii (Table 2). Our study identified T. ovoides as this genus' exclusive species, isolated from nail disease patients. T. ovoides was obtained mainly from women's fingernails, as previously reported, probably due to their frequent exposure to water and house cleaning products. ${ }^{24}$

Although T. ovoides is not incriminated as the Trichosporon genus systemic disease-associated pathogen, like $T$. asahii, we were able to isolate this species at a considerable frequency, as a single microorganism, from onychomycosis in patients living in Rio de Janeiro. It is difficult to discuss our data and the aforementioned publication in terms of Trichosporon species. Although this genus has been widely reviewed, diagnosing it accurately remains a challenge. Consequently, it has been broken down into two names: T. beigelii and T. cutaneum..$^{5,7,8,11,12}$ In fact, Guehó et al. ${ }^{7}$ demonstrated that the term T. ovoides Behrend should replace T. beigelii. The latter species was discussed by some of the authors mentioned in table 2. 5,12,17 However, in line with the reclassification ${ }^{7}$, these isolates could actually be any of the genus' six pathogens, including T. ovoides. Only one previously published study has recovered T. ovoides as a single yeast from an onychomycosis patient's nail (in Maringá, Paraná, Brazil)..$^{28}$

\section{CONCLUSIONS}

We were unable to perform serial nail collection from each patient to investigate T. ovoides' long-term colonization, as Han et al. did ${ }^{12}$ and as strongly recommended by Meireles et al. for diagnosing onychomycosis. ${ }^{29}$ Nor did we conduct molecular sequencing for species identification, and these are limitations we acknowledge. ${ }^{11}$ Nevertheless, unlike other reports, we were able to incriminate $T$. ovoides as the single agent of nail infection. Hence, we propose that this species can play a role in human nail disease. Our study invites future epidemiologic and virulence approaches to determine whether T. ovoides is an important causative agent of onichomycosis in Brazil.

\section{ACKNOWLEDGEMENTS}

We would like to thank all the patients for their participation, as well as Drs. Regina Casz Schechtman and Marize Sacramento Magalhães for allowing us to use the facilities at Santa Casa de Misericórdia in Rio de Janeiro and INCQS/FIOCRUZ, respectively. We are also grateful to Professor Jeferson Carvalhaes de Oliveira for the opportunity to discuss the data presented. 


\section{REFERENCES}

1. Gupta AK, Konnikov N, MacDonald P, Rich P, Rodger NW, Edmonds MW, et al. Prevalence and epidemiology of toenail onychomychosis in diabetic subjects: a multicentre survey. Br J Dermatol. 1998;139:665-71.

2. Araújo AJG, Souza MAJ, Bastos OMP, Oliveira JC. Ocorrência de onicomicose em pacientes em consultórios dermatológicos da cidade do Rio de Janeiro, Brasil. An Bras Dermatol. 2003;78:299-308.

3. Souza EAF, Almeida LMM, Guilhermetti E, Mota VA, Rossi RM, Svidzinski TIE. Freqüência de onicomicoses por leveduras em Maringá, Paraná, Brasil. An Bras Dermatol. 2007;82:151-6.

4. Rippon JW. Dermatophytosis and dermatomycosis. In: Rippon JW. Medical Mycology - the pathogenic fungi and pathogenic actinomycetes. 3rd ed. Philadelphia: Saunders; 1988. p. 169-275.

5. Chagas-Neto TC, Chaves GM, Colombo AL. Update on the genus Trichosporon. Mycopathologia. 2008;166:121-32.

6. Chabasse D, Pihet M. Mycologycal diagnosis of onychomycosis. J Mycol Med. 2014;24:269-78

7. Guého E, Smith MT, de Hoog GS, Billon-Grand G, Christen R, Batenburg-van der Vegte WH. Contributions to a revision of the genus Trichosporon. Antonie Van Leeuwenhoek. 1992 May;61:289-316.

8. Guého E, Improvisi L, de Hoog GS, Dupont B. Trichosporon on humans: a practical account. Mycoses. 1994;37:3-10.

9. Sugita T, Nakajima M, Ikeda R, Matsushima T, Shinoda T. Sequence analysis of the ribosomal DNA intergenic spacer 1 regions of Trichosporon species. J Clin Microbiol. 2002;40:1826-30.

10. Rodriguez-Tudela JL, Diaz-Guerra TM, Mellado E, Cano V, Tapia C, Perkins A, et al. Susceptibility patterns and molecular identification of Trichosporon species. Antimicrob Agents Chemother. 2005;49:4026-34.

11. Colombo AL, Padovan AC, Chaves GM. Current knowledge of Trichosporon spp. and Trichosporonosis. Clin Microbiol Rev. 2011;24:682-700.

12. Han MH, Choi JH, Sung KJ, Moon KC, Koh JK. Onychomycosis and Trichosporon beigelii in Korea. Int J Dermatol. 2000;39:266-9.

13. Koksal F, Er E, Samasti M. Causative agents of superficial mycoses in Istanbul, Turkey: retrospective study. Mycopathologia. 2009;168:117-23.

14. de Hoog GS 2000. Atlas of Clinical Fungi: the ultimate benchtool for diagnosis. 2nd ed. Utrecht, The Netherlands: ASM Press; $1126 \mathrm{p}$.

15. Magalhães AR, Mondino SS, Silva Md, Nishikawa MM. Morphological and biochemical characterization of the aetiological agents of white piedra. Mem Inst Oswaldo Cruz. 2008;103:786-90.

16. Restrepo A, De Uribe L. Isolation of fungi belonging to the genera Geotrichum and Trichosporum from human dermal lesions. Mycopathologia. 1976;59:3-9.

17. Fusaro RM, Miller NG.Onychomycosis caused by Trichosporon beigelii in the United States. J Am Acad Dermatol. 1984;11:747-9.

18. Oyeka CA, Ugwu LO. Fungal flora of human toe webs. Mycoses. 2002;45:488-91.

19. Pontes ZB, Lima Ede O, Oliveira NM, Dos Santos JP, Ramos AL, Carvalho MF. Onychomycosis in João Pessoa city, Brasil. Rev Argent Microbiol. 2002;34:95-9.

20. Araújo AJG, Souza MAJ, Bastos OMP, Oliveira JC. Onicomicoses por fungos emergentes: análise clínica, diagnóstico laboratorial e revisão. An Bras Dermatol. 2003;78:445-55.

21. Archer-Dubon C, Orozco-Topete R, Leyva-Santiago J, Arenas R, Carbajosa J, Ysunza A. Superficial mycotic infections of the foot in native pediatric population: a pathogenic role for Trichosporon cutaneum? Pediatr Dermatol. 2003;20:299302.

22. Svejgaard EL, Nilsson J. Onychomycosis in Denmark: prevalence of fungal nail infection in general practice. Mycoses. 2004;47:131-5.

23. Gunduz T, Metin DY, Sacar T, Hilmioglu S, Baydur H, Inci R, Tümbay E. Onychomycosis in primary school children: association with socioeconomic conditions. Mycoses. 2006;49:431-3.
24. Mugge C, Haustein UF, Nenoff P. Causative agents of onychomycosis - a retrospective study. J Dtsch Dermatol Ges. 2006;4:218-28.

25. Taj-Aldeen SJ, Al-Ansari N, El Shafei S, Meis JF, Curfs-Breuker I, Theelen B,et al. Molecular indentification and susceptibility of Trichosporon species isolated from clinical specimens in Qatar: isolation of Trichosporon dohaense. J Clin Microbiol. 2009;47:1791-9.

26. Alshahni MM, Makimura K, Satoh K, Ishihara Y, Takatori K, Kimura T, et al. Suggested pathogenic role for Trichosporon montevideense in a case of onychomycosis in a Japanese Monkey. J Vet Med Sci. 2009;71:983-6.

27. Alvarez MI, González LA, Castro LA. Onychomycosis in Cali, Colombia. Mycopathologia. 2004;158:181-6.

28. Souza LK, Fernandes OF, Passos XS, Costa CR, Lemos JA, Silva MR Epidemiological and mycological data of onychomycosis in Goiania, Brazil. Mycoses. 2010;53:68-71.

29. Meireles TE, Rocha MF, Brilhante RS, Cordeiro Rde A, Sidrim JJ. Successive mycological nail tests for onychomycosis: a strategy to improve diagnosis efficiency. Braz J Infect Dis. 2008;12:333-7.

\author{
MAILING ADDRESS: \\ Andrea Regina de Souza Baptista \\ Rua Professor Hernani Melo, 101 \\ São Domingos \\ 24210-130 - Niterói - RJ \\ Brazil \\ E-mail: andrearegina@id.uff.br
}

How to cite this article: Magalhães AR, Nishikawa MM, Mondino SSB, Macedo HW, Rocha EMS, Baptista ARS. Trichosporon isolation from human ungueal infections: is there a pathogenic role? . An Bras Dermatol. 2016;91(2):173-9. 